УДК $351: 338$

B. B. Iванюта, к. держ. упр., Житомирський державний технологічний університет

DOI: 10.32702/2306-6814.2019.2.140

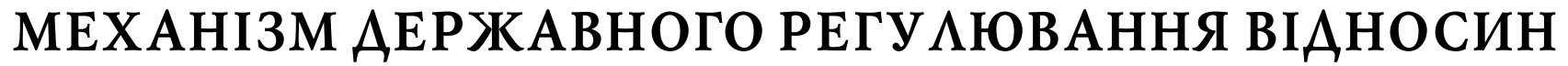 В $\Lambda$ ACНОСТI: ЕКОНОМІКО-ПРАВОВИЙ АСПЕКТ
}

V. Ivaniuta,

Philosophiae doctor, Zhytomyr State Technological University

\section{MECHANISM OF STATE REGULATION OF RELATED PROPERTY: ECONOMIC AND LEGAL ASPECTS}

В статті на основі теоретичного аналізу обгрунтовано методологічні положення щодо формування механізмудержавного регулювання відносин власності, з урахуванням економічного й правового аспекту. З урахуванням економічної і правової природи відносини власності встановлено трифакторність механізму регулювання таких відносин у ринковій економіці. Ринокє основною ланкою, зякої починаються формуються відносини власності, а також виступає одним з механізмів їх регулювання що процесів відчуження, привласнення; володіння; використання та розпорядження. Виробництвопредставлено як головна сфера використання об'єктів власності. Наступним фактором виступає вплив корпоративного менеджменту. Третім фактором представленодержавний регуляторний вплив. Уточнено основі цілі державного регулювання відносин власності.

In the article on the basis of theoretical analysis grounded the methodological positions regarding the formation of the mechanism of state regulation of property relations, taking into account the economic and legal aspects.

Taking into account the economic and legal nature of property relations, a trifactorial mechanism for regulating such relations in a market economy has been established. The market is the main link from which the property relations are formed, and also acts as one of the mechanisms for their regulation of the processes of alienation, appropriation; possession; use and disposal. Production is presented as the main area of use of property. The next factor is the impact of corporate governance. The third factor is the state regulatory influence. The purpose of state regulation of property relations has been clarified, among them: ensuring their civilization, protecting owners from encroachments on their objects by other entities; rational and optimal redistribution of property by the state.

It is shown that in the ratio of economic and legal aspects of property relations - the primary for the subject of regulatory influence is economic. Property relations serve as a framework for the economic system. In the opposite case (characteristic of transitional or transformational systems), when the state tries to form the desired economic relations through the legal mechanism - the legal aspect, including ownership, is artificially determined by the primary in relation to the economy. Certain elements of the economic system are modeled under the established legal framework, which, as a rule, does not give a positive effect. On the contrary, economic reality does not perceive such a right mechanism. The latter, at the same time, is realized in part or in general ignored by economic actors. It is proved that property rights determine the behavior of actors, forming expectations that govern actions. If people expect their profits to be selected (taxes or price imbalance mechanisms) and losses will not be offset, they will try to minimize the risk by taking only short-term projects (for survival), not taking innovation, reducing research costs.

Ключові слова: Відносини Власності, держаВне регулюВання, праВовий механізм, ринкова економіка, суб'єкт господарюВання, узгодження інтересіВ.

Key words: property relations, state regulation, legal mechanism, market economy, subject of management, coordination of interests.

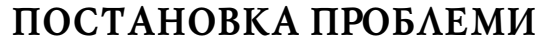

У ЗАГААЬНОМУ ВИГ ЯЯАІ ТА ÏÏ ЗВ 'ЯЗОК ІЗ ВАЖАИВИМИ НАУКОВИМИ ЧИ ПРАКТИЧНИМИ ЗАВААННЯМИ

Державне регулювання відносин власності виступає однією з найактуальніших проблем в умовах ринкової економіки. Сучасний стан цього питання характеризується не сорормованістю в сучасній науці державного управління теорії з цього питання, а також браком досвіду ефективного використання суб'єктами державного управління тією частиною національного багатства, яке знаходиться в державній власності у контексті мож- 
ливостей впливу на економічні процеси. У вітчизняній науковій літературі до цього часу не розроблена загальна теорія державного регулювання відносин власності Цим зумовлюється необхідність подальших досліджень механізму державного регулювання відносин власності у контексті еволюційних процесів в системі державного управління.

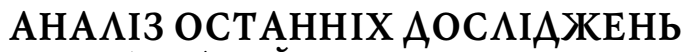 I ПУБ $\Lambda$ ІКАЦІЙ}

Теоретичним і прикладним аспектам вирішення багатогранних проблем реформування відносин власності та їх державного регулювання присвятили значну уваги видатні науковці, серед яких: А. Амоша, Г. Аніловська, В. Бесєдін, М. Бутко, А. Гальчинський, Б. Данилишин, О. Іваницька, О. Канов, І. Лукінов, Л. Мельник, О. Рудченко, О. Пасхавер, Л. Пісьмаченко, Р. Пустовійт, Р. Фрідман та ін.

\section{ПОСТАНОВКА ЗАВААННЯ}

Метою статті $€$ обгрунтування методологічних положень щодо формування механізму державного регулювання відносин власності, з урахуванням економічного й правового аспекту.

\section{ВИК ААА ОСНОВНОГО МАТЕРІААУ АОС АІАЖЕННЯ}

Багатоукладна система економічних інтересів, як й відносини власності, представлена двома типами інтересів суспільних й приватних. Процеси роздержавлення й приватизації, призводячи до змін відносин власності, ускладнюють форми економічних інтересів в рамках зазначених типів. Суспільний інтерес може мати глобальний, національний, державний, регіональний або корпоративний характер. Прояв цього може знаходити через спільний інтерес в межах певного товариства, колективу підприємства, асоціації підприємців тощо [7].

Приватні економічні інтереси передбачають такі форми, як інтереси підприємців, що засновують свою діяльність на приватній власності, корпоративній тощо. При цьому доцільність певної фооми підприємництва визначається можливостями індивідуалізації (в рамках) відносин власності. В таких умовах приватний економічний інтерес стає основою функціонування кожної відповідної структури.

Досліджуючи взаємозв'язок економічних інтересів з формами власності, необхідно використовувати прийняту методологію потрійності інтересів, проте лише у загальному вигляді. Для фрормування практики управління необхідна подальша розробка і поглиблення цього підходу. Форма власності породжує відповідний інтерес, який, у свою чергу, приймає специфрічну фрорму свого прояву - доходу, прибутку, фронду оплати праці, заробітної платні, бюджету. Суспільний інтерес складається як баланс інтересів різних суб'єктів (переважно суб'єктів господарювання).

Система взаємозв' язку інтересів і фрорм власності, структура інтересів в рамках ринкової економіки, заснованої на різноманітті форм власності і суб'єктів господарювання, ускладнюються. Вона відзначається динамічністю і суперечливістю. Узгодження таких інтересів в ринковій економіці здійснюється не за вертикальним принципом, а за принципом консенсусу. В основі такого підходу лежить перетворення приватного інтересу на початковий тип всієї системи, а також правова рівність різних фрорм власності. У таких умовах узгодження інтересів у формі консенсусу виникає з того, що спільність економічного життя, що грунтується на розподілі праці між суб'єктами ринкових відносин, фоорує взаємозв'язану систему типів, форм і різновидів інтересів, кожний з яких є водночас відособленим й частиною цілого. В результаті в системі складається діалектична спільність різноспрямованих інтересів. Така спільність припускає необхідність їх узгодження, а відособленість рівноправних суб'єктів власності не допускає ієрархічної підлеглості, обумовлюючи в ході їх узгодження використання консенсусу в моментах перетину інтересів різних типів, форм й різновидів [6].

В епоху вільної конкуренції відносини власності у всій своїй багатоаспектності регулюються кількома механізмами. Це обгрунтовується наступним. У первинному виробничому осередку економіки, тобто на рівні підприємства, корпорації, завжди здійснюється свідома організація виробничого процесу. Тобто, тріада проблем, які притаманні кожній економічній системі у товарному господарстві вирішується не лише ринковим механізмом спонтанно (стихійно), але і свідомо на мікрорівні кожним товаровиробником-підприємцем.

На рівні суб'єктів господарювання ринкові зв'язки між ними, якщо й управляються свідомо, проте в кінцевому підсумку регулюються саме ринковим механізмом, що $\epsilon$ цілком об'єктивно. Виробник виробляє ті товари і в такій кількості, яку він розраховує реалізувати на ринку. При цьому необхідно дотримуватися встановлених ринком стандартів якості продукції та послуг, рівня цін, які склалися на певний час, тобто враховувати кон'юнктуру ринку.

Таким чином, економічний суверенітет власникапідприємця у ринковій економіці є відносний. Він завжди обмежений кон'юнктурою ринку, а вона, в свою чергу, визначається об'єктивними законами товарного господарства. Ринок примушує всіх суб'єктів, всіх власників, що фрункціонують в ринковому середовищі дотримуватися його законів. Тому відносини власності у ринковій економіці значною мірою управляються ринком. Він регулює зв'язки між суб'єктами на всіх видах ринку, у тому числі на ринку праці, фрункціонування всієї ринкової інфрраструктури, а також відносини безпосередньої господарської діяльності. Тому не випадково в теорії державного регулювання економіки питання про ринковий механізм є одним з основних. Пізнання його сутності дає змогу зрозуміти тезу А. Сміта про "невидиму руку", яка організовує товарне господарство і управляє ним.

У товарному господарстві відносини власності не просто нерозривно пов'язані з економічними відносинами. Вони їх найважливіша складова, тобто є каркасом для економічної системи. Ринок $є$ основною ланкою, де відбувається процес відчуження і привласнення, тобто починається власність. Виробництво $€$ головною сферою використання об'єктів (виробничих ресурсів) власності. Одночасно ринок $є$ одним із головних механізмів, які регулюють "рух" відносин власності щодо: відчуження - привласнення; володіння; користування та розпорядження об'єктами власності. Разом з тим, з самого початку виникнення приватної власності і похідних від неї форм у відносини власності почала 
втручатися держава. Держава виконує регулюючу функцію, тобто відносини власності регулюються не тільки за допомогою свідомого менеджменту та стихійного ринкового механізму, але й свідомо державою.

При цьому дискусійним виглядає твердження ряду дослідників, згідно з яким в останні десятиліття в розвинутих країнах склався двофракторний механізм регулювання економіки, що включає механізм ринкової конкуренції та механізм державного регулювання [1]. У сучасних моделях економіки ринкового типу склався трифакторний механізм регулювання: управління на рівні певної організаційно-правової форми господарства іїх об'єднання (внутрішньогосподарській і корпоративний менеджмент); ринок; державне регулювання. Окрім того, певний вплив на регулювання економіки здійснюють різні недержавні інститути (асоціації підприємців, профрспілки, споживачів).

При свідомому регулюванні відносин власності держава ставить перед собою певні цілі. По-перше, регулювання відносин власності з метою їх цивілізації і захисту власників від посягання на їх об'єкти власності інших суб'єктів. Мова йде про юридичний аспект відносин власності.

По-друге, перерозподіл об'єктів власності державою. 3 одного боку, вона відбирає їх частину у недержавних суб'єктів. 3 іншого - розподіляє їх. Це досягається за допомогою, насамперед, податків і держбюджету. Частину зібраних коштів держава використовує для забезпечення виконання своїх функцій, іншу - через трансорертні платежі передає тим суб'єктам, які мають найбільшу у цьому потребу.

Розглянемо механізми державного регулювання власності. Одним із традиційних і вагомих механізмів державного регулювання відносин власності $€$ правовий механізм (господарське право), що охоплює широке коло питань. Але більшість з них пов' язані з відносинами власності. 3 моменту виникнення приватної власності з'явилася потреба її державного регулювання, забезпечення правового статусу, охорони. Так виникло право власності. Категорія власності почала досліджуватися в правовому аспекті. Як відомо, право передбачає сукупність загальнообов'язкових норм поведінки. Вони встановлюються в суспільстві традиційно або затверджуються і підтримуються державою. При державно-правовому регулюванні господарської діяльності усі реально існуючі відносини власності й інші економічні зв'язки між людьми стають загально визнаними правовими нормами, що підлягають обов'язковому виконанню.

Завдяки праву значне коло господарських зв'язків між людьми набирає характеру правовідносин. Такі правові норми закріплюють існуючі відносини власності і регулюють розподіл праці та її продуктів між членами суспільства. Так, відомий англійський фрілософр і економіст Д. Юм, прихильник А. Сміта і попередник І. Канта, стверджував, що ніхто не може сумніватися, що договір про розподіл власності і про стабільність володіння нею $є$ найбільш необхідною умовою для упорядкування людського суспільства [9].

Щодо схеми фрункціональних зв'язків між основними складовими державного сектора. Економічні відносини між складовими державного сектора економіки включають: суб'єкти власності, об'єкт власності і право власності держави, виникають в процесі їх взаємодії з приводу реалізації права власності держави на об'єкт власності. Часто суб'єкти і об'єкти державної власності (як сторони відносин) взаємодіють в цілях виконання господарських дій [8].

Зазначимо, необхідність правового механізму регулювання відносин власності обумовлена наступним. Будь-яке суспільство через обмеженість ресурсів, відособленість приватних індивідуальних інтересів та їх розбіжність із суспільними потребує регулювання господарської діяльності людей. Ринкова економіка не $є$ винятком і потребує розробки особливих норм економічної поведінки суб'єктів та їх дотримання. Тобто, вплив "невидимої руки" має бути доповнено механізмом правового регламентування усіх сфер суспільного життя. Вольові стосунки закріплюються в структурі прав і через систему стимулів визначають норми поведінки людей. Без вироблених державою правил гри неможлива цивілізована ринкова економіка. Сам механізм ринку неспроможний її сорормувати і забезпечити нормальне функціонування. Кожний суб'єкт ринкової економіки за першою нагодою намагається вийти з економічного поля, у тій або іншій мірі оминути принципи і правила, що обумовлюються законами ринку. Достатньо звернути увагу на прагнення виробників до монопольного становища на ринку. Монополізм на практиці набув певного поширення і навіть загрожував руйнацією основ товарного господарства.

В сучасних моделях економіки ринкового типу значимість правового механізму істотно посилилася. Тут позначається дія багатьох умов і чинників. Відзначимо головні з них: зростання економічної діяльності держави, що потребує юридичної оболонки, тобто прийняття правових актів державними інститутами, що упорядкують економічну діяльність самої держави; ускладнилися економічні відносини власності і господарювання, відбувається змішування або взаємопроникнення індивідуальної приватної власності, сфрормувалося багато видів і підвидів при ватно-колективних форм власності, відбувається переплетення власності, господарювання й управління. Все це потребує правової організації відносин власності й господарювання, які все більш ускладнюються; необхідність підвищення науковості господарського права, організації ефективної його реалізації. Потрібна однозначність тлумачень кожної норми, конкретна адресність. Тоді спрощуються механізми їх доведення до виконавців. Проте, у будь-якому випадку, тобто при максимально можливій обгрунтованості господарського права потрібен постійний контроль державних інститутів за його суворим дотриманням. Оскільки будь-який суб'єкт ринкової економіки (аналогічно щодо дії економічних законів) прагне з першою вигідною нагодою вийти з правового поля. I така можливість нерідко реалізується. Особливо це стосується податкового, охорони навколишнього середовища, захисту прав власності. Інший не менш важливий приклад - наявність фактично у всіх країнах тіньової економіки, а отже, і тіньового ринку. Від офіційної тіньова економіка відрізняється саме тим, що її діяльність суперечить чинному законодавству і праву. Тіньовій економіці властиві свої різновиди. Частина її має кримінальне походження і практично не залежить від власне ринкової економіки. Прикладом може служити корупція, історія якої обчислюється тисячоліттями. Другий напрям тіньової економіки за змістом і формою $є$ 
дзеркальним відбитком офріційної економіки і залежить від існуючих правових норм, у той же час порушуючи їх. Наприклад, фральсифікація торгових марок, коли вироби відносно низької якості видаються за продукцію всесвітньо відомих фрірм, приносячи їх виробникам фактично нелегальні прибутки, а споживачам - збитки. Є чимало видів підпільного бізнесу (наркобізнес, незаконна торгівля зброєю), контрабандна торгівля тощо. Одним із проявів тіньової економіки с несплата податків, тобто приховання прибутків від оподаткування.

Необхідно відзначити, що в ринковій економіці багато в чому не збігаються інтереси ії̈ головних суб'єктів - роботодавців і найманих працівників. А в процесі розподілу новоствореної вартості на заробітну плату i прибуток вони навіть протилежні. У рамках даного розміру новоствореної власності збільшити прибуток можна тільки за рахунок скорочення заробітної плати, i, навпаки, збільшити заробітну плату за рахунок зменшення прибутку.

У кінцевому підсумку держава як правовий суб'єкт регулює господарську діяльність з метою її цивілізації, визначає велике коло прав і обов'язків всіх суб'єктів економіки, норм їх взаємовідносин, функціонування банківської і страхової діяльності, забезпечує конкурентний порядок, регулює зовнішньоекономічні зв'язки. Держава в контексті правового інституту $є$ арбітром вищої інстанції в економічних відносинах суспільства.

Таким чином, у ринковій економіці держава створює правове поле і для себе як суб'єкта економіки, й в інтересах недержавних суб'єктів. Право націлене на нейтралізацію можливої агресивності суб'єктів ринкової економіки стосовно один до одного, включаючи своїх партнерів і особливо конкурентів, усунення негативних аспектів складних взаємозв'язків між економічно суверенними виробниками, об'єднаними суспільним поділом праці, а тому змушеними вступати у взаємні відносини через посередництво ринку. В цілому наявність чітко зафріксованих державою прав полегшує взаємне розуміння інтересів і намірів усіх суб'єктів економіки, тобто існування цивілізованих відносин між ними.

Оскільки відносини власності є елементом всієї економічної системи, тому не випадково в правому механізмі основне місце займають закони й інші нормативні акти, прямо або опосередковано пов' язані з відносинами власності.

Щодо правового аспекту власності, сам термін був сфрормований як категорія у фрілософрії права. Із розвитком суспільного виробництва відбулось фрормування підходу до власності як до ключової соціально-економічної категорії. На сьогодні практично загальновизнаною $€$ концепція, згідно з якою власність $€$ таким елементом економічної системи, якому притаманні властивості подвійного характеру: це економічна і водночас юридична категорія. Тобто в категорії "власність" поєднуються як економічні, так і правові аспекти, що доповнюють один одного [8].

Відносно ієрархії двох аспектів власності більшість вчених визначають, що власність обумовлена економічно і $\epsilon$ наслідком певних економічних відносин як дійсного способу привласнення [7, с. 157]. При цьому юридичний аспект $є$ формою прояву реальних економічних відносин власності, що входить до надбудовних відносин та залежить від волі й свідомості людей [5, с. 245]. Теорія прав власності лише юридично затверджує ті процеси, що відбуваються в економіці, і цим сприяє подальшому розвитку економічних явищ [4, с. 13]. За своєю субстанціональною природою правові відносини власності $є$ не реальними (економічними), а вольовими, ідеальними відносинами, які не утворюють субстанції виробничих відносин ічерез те перебувають поза сорерою виробництва [3, с. 34].

Подібні твердження цілком відповідають ортодоксальним положенням марксизму. У немарксистській течії власність завжди досліджувалась переважно в правовому аспекті. Положення про власність як вольове, юридичне відношення отримало наукове обгрунтування в роботах Г. Гегеля. В подальшому його розвинули Гейнец, Закє, Мюльбергер, Прудон та інші.

В сучасній науці країн сорормувалась навіть теорія власності, родоначальниками якої $є$ Р. Коуз і А. Алчян (США), згідно з якою власністю $€$ не ресурс сам по собі. Важливо, що відносини власності розглядаються як санкціоновані суспільством, а не лише державою. А це не тільки закони, але й звичаї, і моральні принципи, що впливають на поведінку людей, оскільки визначають їх права власності. Узагальнений досвід свідчить про те, що спроби законодавчого врегулювання усіх процесів $\epsilon$ безперспективними. Певні аспекти обумовлюються лише здоровим глуздом та суспільною мораллю, які є значно ширшими від можливостей державного врегулювання [9].

Необхідно зазначити, що права власності визначають поведінку суб'єктів, формуючи очікування, які керують діями. Якщо люди очікують, що їх прибутки відбиратимуться (податки, чи через механізм цінового дисбалансу), а збитки не будуть компенсовані, то вони намагатимуться мінімізувати ризик, приймаючи лише короткострокові проекти (для виживання), не сприймаючи нововведень, скорочуючи витрати на дослідження [8, с. 21].

Положення про те, що правові відносини похідні від економічних та віддзеркалюють їх, - у цілому слід сприймати позитивно. Не викликає сумніву той факт, що із зміцненням інституту держави вона намагається зафріксувати у відповідних юридичних законах та інших нормативних документах більш широке коло вже існуючих відносин. Відносини власності не $є$ виключенням. Проте $\epsilon$ випадки, коли держава намагається за допомогою юридичних законів і нормативних документів сфрормувати бажані для неї економічні відносини. Особливо це характерно для свідомої розбудови в економічних системах перехідного або трансорормаційного типу у країнах, що розвивається. У такому випадку юридичний аспект економічної системи, а відповідно й власності, $€$ первинним по відношенню до економіки. Остання, а точніше певні її елементи, моделюється під вже створену правову базу. Проте не завжди це дає позитивний ефрект. Практика свідчить, що частіше економічна дійсність не сприймає такого правого механізму. Він (механізм) не реалізується повною мірою, або ігнорується тими, хто повинен його реалізувати. Але, у деяких випадках, особливо коли правова модель націлена на розбудову прогресивних економічних процесів, фрорм господарювання тощо відповідний правовий механізм може бути успішно реалізований.

В обох випадках, тобто коли пріоритетними $є$ економічні відносини, або право, власність виступає таким 
елементом економічної системи, що має властивості подвійного характеру: це економічна й одночасно юридична категорія. У категорії "власність" поєднуються як економічні, так й правові аспекти механізму державного впливу, що доповнюють один одного.

В юридичному аспекті власність у більшості випадків фріксує реальні соціально-економічні відносини. Проте не всі вони, у тому числі власності, набирають правової фрорми. Зокрема, ринкові угоди відчуження - привласнення не завжди оформлюються юридично. В цілому власність як правове поняття показує як закріплюється правом порядок майнових відносин, тобто приналежність об'єкта власності конкретним юридичним або фрізичним особам (суб'єктам власності).

\section{ВИСНОВКИ 3 ПРОВЕАЕНОГО АОС ІАЖЕННЯ І ПЕРСПЕКТИВИ ПОАА НАПРЯМІ}

На основі загального аналізу економічної і правової природи відносини власності встановлено трифакторність механізму регулювання таких відносин у ринковій економіці. Ринок $є$ основною ланкою, з якої починаються (формуються) відносини власності, а також виступає одним з механізмів їх регулювання що процесів відчуження, привласнення; володіння; використання та розпорядження. Виробництво представлено як головна сорера використання об'єктів власності. Наступним фактором виступає вплив корпоративного менеджменту. Третім фактором представлено державний регуляторний вплив. Уточнено основі цілі державного регулювання відносин власності, серед яких: забезпечення їх цивілізованості, захисту власників від посягань на їх об'єкти з боку інших суб'єктів; раціональний та оптимальний перерозподіл об'єктів власності державою.

Показано, що у співвідношенні економічного і правового аспектів відносин власності - первинним для суб'єкта регуляторного впливу є саме економічний. Відносини власності виступають у якості каркасу економічної системи. У протилежному випадку (характерно систем перехідного або трансформаційного типу), коли держава намагається через правовий механізм сорормувати бажані економічні відносини - юридичний аспект, у тому числі щодо власності, штучно визначається первинним стосовно економіки. Певні елементи економічної системи моделюється під створену правову базу, що, як правило, не дає позитивного ефекту. Навпаки, економічна дійсність не сприймає такого правого механізму. Останній при цьому або реалізується неповною мірою, або взагалі ігнорується економічними суб'єктами.

\section{Література:}

1. Аніловська Г.Я. Державний фрактор трансорормаційних перетворень в економіках перехідного типу / Г.Я. Аніловська. - Львів: Вид-во ЛКА, 2002. - 324 с.

2. Бутко М.П. Регіональні особливості економічних трансформацій в перехідній економіці / М.П. Бутко. К.: Знання України, 2005. - 476 с.

3. Канов О. Державна власність в економічній системі суспільства: деякі теоретичні аспекти / О. Канов / / Економіка України. - 1996. - № 2. - С. 33-36.
4. Клапгам Р. Власність і ринкова економіка / Р. Клапгам; пер.з нім. І. Невмержицький. - К.: Заповіт, 1996. - 148 c.

5. Петришина Н.В. Роль держави у забезпеченні економічного розвитку / Н.В. Петришина / / Теоретичні та прикладні питання економіки: зб. наук. праць Київського національного університету імені Т.Г.Шевченка / за заг. ред. проф. Єханурова ЮЛ., Шегди А.В. - К.: Видавничо-поліграфічний центр "Київський університет", 2007. - Вип. 13. - С. 244-250.

6. Пустовійт Р.Ф. Інституціональне середовище підприємництва в трансформаційній економіці: [монографрія] / Р.Ф. Пустовійт. - Черкаси: Брама-Україна, 2006. - 372 c.

7. Рудченко О.Ю. Реформування відносин власності в Україні / О.Ю. Рудченко, С. Ю. Лєдомська. - К.: КФ ДП НДЕІ, 2004. - 502 с.

8. Фрідман Р. Приватизація в період переходу до ринкової економіки / Р. Фрідман, А. Рапачинський. К.: Основи, 2004. - 351 с.

9. International comparison of corporate governance guidelines and codes of best practices in developing and emerging markets / Holly J.Gregory. - New York: Weil, Gotshal \& Manges LLP, 2001. - 126 р. [Електронний ресурс]. - Режим доступу: http://www.afic.am/

\section{References}

1. Anilovs'ka, H.Ya. (2002), Derzhavnyj faktor transformatsijnykh peretvoren' v ekonomikakh perekhidnoho typu [State factor of transformational transformations in transition economies], Vyd-vo LKA, Lviv, Ukraine.

2.Butko, M.P. (2005), Rehional'ni osoblyvosti ekonomichnykh transformatsij $v$ perekhidnij ekonomitsi [Regional features of economic transformations in transition economics], Znannia Ukrainy, Kyiv, Ukraine.

3. Kanov, O. (1996), "State property in the economic system of society: some theoretical aspects", Ekonomika Ukrainy, vol. 2, pp. 33-36.

4. Klapham, R. (1996), Vlasnist' i rynkova ekonomika [Property and market economy], Zapovit, Kyiv, Ukraine.

5. Petryshyna, N.V. (2007), "The role of the state in ensuring economic development", Teoretychni ta prykladni pytannia ekonomiky: zb. nauk. prats' Kyivs'koho natsional'noho universytetu imeni T.H.Shevchenka, Vyp. 13, pp. 244-250.

6. Pustovijt, R.F. (2006), Instytutsional'ne seredovysche pidpryiemnytstva $v$ transformatsijnij ekonomitsi [The institutional environment of entrepreneurship in a transformational economy], Brama-Ukraina, Cherkasy, Ukraine.

7. Rudchenko, O.Yu. and Liedoms'ka S. Yu. (2004), Reformuvannia vidnosyn vlasnosti v Ukraini [Reforming Property Relations in Ukraine], KF DP NDEI, Kyiv, Ukraine.

8. Fridman, R. and Rapachyns'kyj, A. (2004), Pryvatyzatsiia $v$ period perekhodu do rynkovoi ekonomiky [Privatization in the transition to a market economy], Osnovy, Kyiv, Ukraine.

9. Holly J. Gregory (2001), "International comparison of corporate governance guidelines and codes of best practices in developing and emerging markets". - New York: Weil, Gotshal \& Manges LLP, pp. 126, available at: http://www.afic.am/

Стаття надійшла до редакчї 18.01.2019p. 